\title{
Effects of Dinotefuran and Imidacloprid on Target and Non-target Arthropods on American Elm
}

\author{
Adrianna Szczepaniec, Brian B. Raupp, and Michael J. Raupp
}

\begin{abstract}
Neonicotinoid insecticides are a relatively new class of compounds with excellent efficacy against a broad assemblage of key insect pests of woody plants. Unfortunately, the use of one neonicotinoid, imidacloprid, has been linked to secondary outbreaks of several species of spider mites on different trees and shrubs. Dinotefuran is another neonicotinoid insecticide now widely used by arborists to manage insects, including egregious borers like emerald ash borer. Researchers tested a hypothesis that applications of dinotefuran to American elms (Ulmus americana) elevated populations of a spider mite, Tetranychus schoenei, and rust mites in the family Diptilomiopidae, and found no indication that dinotefuran elevated densities of either mite. Applications of imidacloprid elevated densities of T. schoenei, but not Diptilomiopidae. Both neonicotinoids were highly efficacious in reducing abundances of European elm scale, Eriococcus spuria, and elm cockscomb gall aphid, Colopha ulmicola.

Key Words. Cockscomb Gall Aphid; Colopha ulmicola; Diptilomiopidae; Dinotefuran; Eriococcus spuria; European Elm Scale; Imidacloprid; Rust Mites; Secondary Pest Outbreak; Spider Mites; Tetranychus schoenei; Ulmus americana.
\end{abstract}

Neonicotinoids are a relatively new and important class of systemic insecticides used to manage insect pests of many crops, including trees and shrubs. These nitroguanidine compounds affect a broad spectrum of insects by disrupting their acetylcholine nerve cell receptors (Mullins 1993). Of several neonicotinoid compounds introduced into the arboricultural marketplace, imidacloprid was the first to be widely used owing to its efficacy against several key insect pests of trees and shrubs including aphids (Sclar and Cranshaw 1996; Layton and Ma 2009), lace bugs (Gill et al. 1999; Szczepaniec and Raupp 2007), scales (Sclar and Cranshaw 1996; Frank 2012), psyllids (Young 2002), adelgids (Stewart and Horner 1994; Doccola et al. 2003; Webb et al. 2003; Cowles et al. 2006), palm bugs (Ali et al. 2010), leaf beetles (Sclar and Cranshaw 1996; Lawson and Dahlsten 2003), flatheaded borers (Herms 2003; Rebek et al. 2008; Smitley et al. 2010), roundheaded borers (Wang et al. 2005), leaf-feeding scarabs (Frank et al. 2007), and leafminers (d'Eustachio and Raupp 2001; Gill et al. 2002). Not only did imidacloprid prove lethal to these pests, but it also reduced damage to red maple (Acer rubrum) caused by leafhoppers (Empoasca fabae) and flatheaded appletree borers (Chrysobothris femorata) (Oliver et al. 2009; Oliver et al. 2010). Imidacloprid reduced defoliation of lindens (Tilia sp.) by Japanese beetles (Popillia japonica) (Frank et al. 2007) and periodical cicadas (Ahern et al. 2005). Imidacloprid also limited ash mortality associated with infestations of emerald ash borer (Agrilus planipennis) (Rebek et al. 2008; Smitely et al. 2010). Due to its efficacy against wood-boring beetles, it has been widely recommended for controlling emerald ash borer (Herms et al. 2009) and used to treat thousands of trees to manage Asian longhorned beetle (Anoplophora glabripennis) (Szczepaniec et al. 2011).
A second neonicotinoid, dinotefuran, entered the arboricultural trade several years after imidacloprid. Applications of dinotefuran have proven to be effective in controlling palm bug (Xylastodoris luteolus) (Ali et al. 2010), euonymus scale (Unaspis euonymi) (Frank 2012), crapemyrtle aphid (Tinocallis kahawaluokalani) (Layton and Ma 2009), California red scale (Aonidiella aurantii) (Ludwig 2011), potato leafhopper (Empoasca fabae) (Oliver et al. 2009), flathead appletree borer (Oliver et al. 2010), and hemlock wooly adelgid (Adelges tsugae) (Frank and Lebude 2011).

Despite their storied successes in controlling many important pests in landscapes, neonicotinoids have not been problemfree. Several cases of secondary pest outbreaks have now been linked to the application of neonicotinoids to trees and shrubs (Raupp et al. 2010). In 1998, Sclar et al. reported outbreaks of the honeylocust spider mite (Platytetranychus multidigituli) on honeylocust (Gleditsia triacanthos) following the application of imidacloprid. This report was soon followed by several others that documented outbreaks of spider mites following the application of imidacloprid. Elevated populations of mites were documented in plant-spider mite associations including hemlock (Tsuga canadensis) with spruce spider mite (Oligonychus ununguis) (Raupp et al. 2004), rose bushes (Rosa sp.) with twospotted spider mites (Tetranychus urticae) (Gupta and Krischik 2007), elm (Ulmus americana) with Tetranychus schoenei (Szczepaniec et al. 2011), and boxwood (Buxus sempervirens) with boxwood spider mite (Eurytetranychus buxi) (Szczepaniec and Raupp 2012a; Szczepaniec and Raupp 2012b). Spider mite outbreaks on elms and boxwoods following applications of imidacloprid were linked to enhanced fecundity of spider mites following consumption of foliage from plants treated with imidacloprid (Szczepaniec et al. 2011; Szczepaniec and Raupp 2012b). 
Due to dinotefuran's mode of action being similar to that of imidacloprid as a nicotinic acetylcholine receptor agonist and its widespread use in the arboricultural industry as a preventative and curative insecticide for controlling invasive coleopteran borers (Herms et al. 2009; Raupp et al. 2010; Szczepaniec et al. 2011; Raupp et al. 2012), the study authors wanted to know if applications of dinotefuran resulted in elevated populations of spider mites. Based on previous studies, which demonstrated the propensity of American elm to experience moderate to severe secondary outbreaks of spider mites following the application of imidacloprid (Szczepaniec et al. 2011), researchers selected this important landscape tree and its associated spider mite, T. schoenei, as test subjects. The objectives were twofold. First, researchers sought to determine if applications of dinotefuran resulted in elevated densities of spider mites and rust mites (Diptilomiopidae) on American elms. Second, having observed reductions in populations of sucking insects, such as European elm scale (E. spuria), following applications of imidacloprid to American elms (Sclar and Cranshaw 1996; Szczepaniec et al. 2011), the effects of dinotefuran and imidacloprid on the abundance of two sucking insects, European elm scale and elm cockscomb gall aphid (Colopha ulmicola), were examined.

\section{MATERIALS AND METHODS}

Ulmus americana used in this study were part of a common garden of 27 elms planted at the University of Maryland's Paint Branch Turf Research Facility (College Park, Maryland, U.S.). The research plot was established in July 2005. Containerized elms approximately $2.5 \mathrm{~cm} \mathrm{DBH}$ were planted in native soil (Keyport Silt Loam) on $4 \mathrm{~m}$ centers in three rows of nine trees. Trees received approximately $5 \mathrm{~cm}$ of shredded hardwood mulch after planting and supplemental irrigation on a weekly basis in the summer and autumn of 2005 on weeks with no rainfall. Thereafter, rainfall was the only source of water except when insecticides were applied. At the time of installation, all trees received a single application of fertilizer (Osmocote 14-14-14) at the recommended rate of $0.32 \mathrm{~kg}$ per $9.3 \mathrm{sq} \mathrm{m}$ (Gillman and Rosen 2000).

In June 2006, trees were assigned to one of three treatments in a Latin square design. Nine trees served as untreated controls. Nine trees received imidacloprid and nine trees received dinotefuran. Applications of insecticides were made on June 5, 2006; May 2, 2007; and May 13, 2008. Imidacloprid was applied as a single soil drench application $\left(\right.$ Merit $^{\circledR} 75 \mathrm{WP}$, Bayer Environmental Science, Research Triangle Park, North Carolina, U.S.) at the label rate of $1.96 \mathrm{~g}$ per $2.54 \mathrm{~cm} \mathrm{DBH}$ of trunk in $7.6 \mathrm{~L}$ of water. Dinotefuran was applied as a single soil drench application (Safari $20 \mathrm{SG}^{\circledR}$, Valent USA Corporation, Walnut Creek, California, U.S.) at the label rate of $12 \mathrm{~g}$ per $2.54 \mathrm{~cm} \mathrm{DBH}$ of trunk in $7.6 \mathrm{~L}$ of water. Untreated control trees received a basal drench of $7.6 \mathrm{~L}$ of water on the dates that insecticides were applied. Mulch was removed around the base of the tree to permit infiltration of water and insecticides.

On June 14, 2006, two branches 15 to $30 \mathrm{~cm}$ long on opposite sides of each tree were removed. The branches and excised foliage from each tree were collectively bagged, placed in a cooler, brought to the laboratory, and refrigerated until spider mites and other arthropods were counted using a dissecting microscope. All spider mites, rust mites, scales, and aphids on adaxial and abaxial surfaces of the two most terminal, fully expanded leaves were counted. To compute densities of arthropods, leaf area was mea- sured using an area meter (Model LI-31100C, Li-Cor, Lincoln, Nebraska, U.S.) and abundances of all arthropods were expressed as the number of individuals per $\mathrm{cm}^{2}$ of leaf area. This method of sampling was used previously to estimate densities of arthropods on Ulmus americana in landscapes (Szczepaniec et al. 2011). Researchers considered samples taken in June 2006 as estimates of arthropod abundance prior to the effects of insecticides (precounts). Soil applications of neonicotinoids generally require several weeks to reach the canopy of a tree (Herms et al. 2009) and these samples were taken nine days after insecticide applications.

The effects of imidacloprid and dinotefuran on arthropod abundance were evaluated in the summer of 2008. On June 24, July 21, August 11, and September 11, two branches 15 to $30 \mathrm{~cm}$ long on opposite sides of the tree were removed. The branches and excised foliage from each tree were collectively bagged, placed in a cooler, brought to the laboratory, and refrigerated until spider mites and other arthropods were counted using a dissecting microscope. All spider mites, rust mites, and scales on adaxial and abaxial surfaces of the five most terminal, fully expanded leaves were counted. Leaf areas were measured and densities of arthropods were expressed as the number of individuals per $\mathrm{cm}^{2}$ of leaf area. Aphids were sampled on two dates, July 21 and August 11, and counted by dissecting the galls through a small incision on the abaxial surface of each sampled leaf. The mean seasonal abundance for each taxon was calculated by computing the mean across all four sample dates for spider mites, rust mites, and scales, and for two sample dates for gall aphids. The mean seasonal abundance for each of the four taxa sampled were tested for differences among treatments by way of comparison.

Estimates of mean seasonal abundances were not normal for any of the taxa studied, nor were their variances homogeneous due to a preponderance of samples with zeros. Therefore, comparisons of arthropod abundance among treatments were conducted with Kruskal-Wallis one-way nonparametric analyses of variance (Zar 1999; Statistix ${ }^{\circledR}$ Analytical Software 2003, Tallahassee, Florida, U.S.). Following each analysis, an all-pairwise comparisons test was used to resolve differences among treatments (Statistix ${ }^{\circledR}$ Analytical Software 2003, Tallahassee, Florida, U.S.).

\section{RESULTS AND DISCUSSION}

Samples taken on June 14, 2006, did not reveal significant differences in the abundance of $T$. schoenei (Kruskal-Wallis Statistic $=0.2267$, d.f. $=2, \mathrm{P}=0.8929)$, Diptilomiopidae mites (Kruskal-Wallis Statistic $=1.5979$, d.f. $=2, \mathrm{P}=0.4498$ ), E. spuria (Kruskal-Wallis Statistic $=2.7368$, d.f. $=2, \mathrm{P}=0.2545$ ), or Colopha ulmicola (test not possible, no aphids present). By contrast, applications of imidacloprid significantly increased the abundance of $T$. schoenei over the course of the 2008 study (Figure 1). The mean seasonal abundance of T. schoenei on elms treated with imidacloprid was approximately ten times greater than the abundance of mites on untreated elms, and five times greater than on elms treated with dinotefuran (Kruskal-Wallis Statistic $=15.8329$, d.f. $=2, \mathrm{P}=0.0004)$. Dinotefuran showed a slight trend to elevate densities of $T$. schoenei; this difference, however, did not differ significantly from densities of mites on untreated elms over the course of the study (Figure 1).

The mean seasonal abundance of Diptilomiopidae mites did not differ among treatments (Kruskal-Wallis Statistic $=0.9982$, d.f. $=2$, $\mathrm{P}=0.6071)$. Their abundances over the course of the study were $0.608 \pm 0.33$ (mean \pm standard error) mites per $\mathrm{cm}^{2}$ on untreated 
elms, $0.48 \pm 0.14$ mites per $\mathrm{cm}^{2}$ on elms treated with dinotefuran, and $0.55 \pm 0.18$ mites per $\mathrm{cm}^{2}$ on elms treated with imidacloprid.

The mean seasonal abundance of E. spuria on untreated elms was significantly greater than that of elms treated with dinotefuran or imidacloprid (Kruskal-Wallis Statistic $=15.8329$, d.f. $=2, P=0.0004$ ) (Figure 2). The mean seasonal abundance of E. spuria did not differ between trees treated with imidacloprid and those treated with dinotefuran (Figure 2). Similarly, both insecticides significantly reduced numbers of the gall-forming aphids compared to untreated elms (KruskalWallis Statistic $=10.3159$, d.f. $=2, \mathrm{P}=0.0055$ ) (Figure 3). There was also no difference in densities of $C$. ulmicola between elms treated with imidacloprid and dinotefuran (Figure 3).

Pre-count samples taken shortly after the application of neonicotinoid insecticides revealed a lack of differences in arthropod densities on elm leaves. However, after three successive years of applications, populations of $T$. schoenei were significantly elevated on elms treated with imidacloprid but not

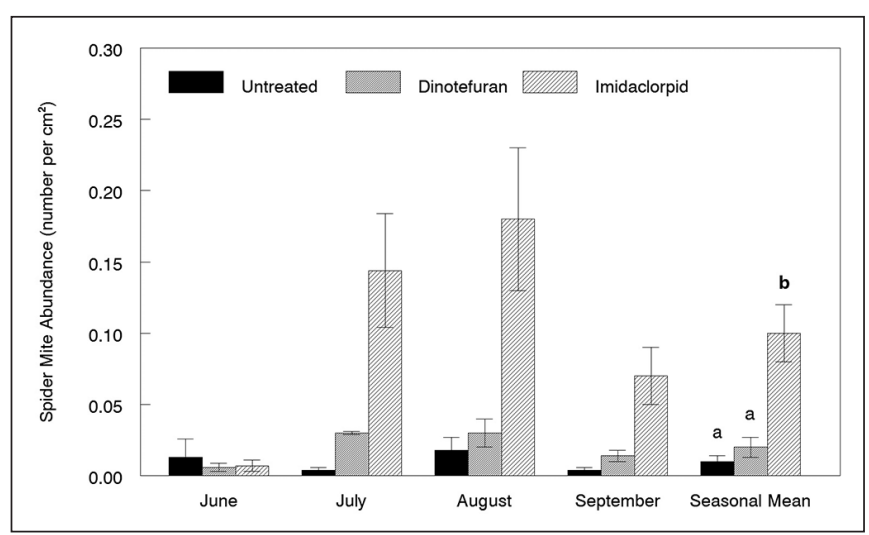

Figure 1. Effects of dinotefuran and imidacloprid on the abundance of Tetranychus schoenei on four sample dates and seasonally (average of all four dates) on Ulmus americana. Bars represent means and vertical lines represent standard errors. Means that share a common letter do not differ significantly by an all-pairwise comparisons test $(P<0.05)$.

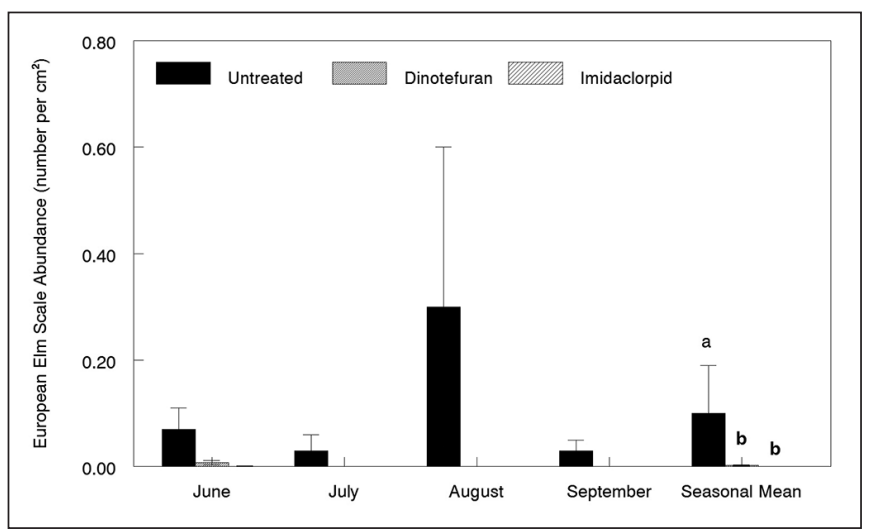

Figure 2. Effects of dinotefuran and imidacloprid on the abundance of Eriococcus spuria on four sample dates and seasonally (average of all four dates) on Ulmus americana. Bars represent means and vertical lines represent standard errors. Means that share a common letter do not differ significantly by an all-pairwise comparisons test $(P<0.05)$.

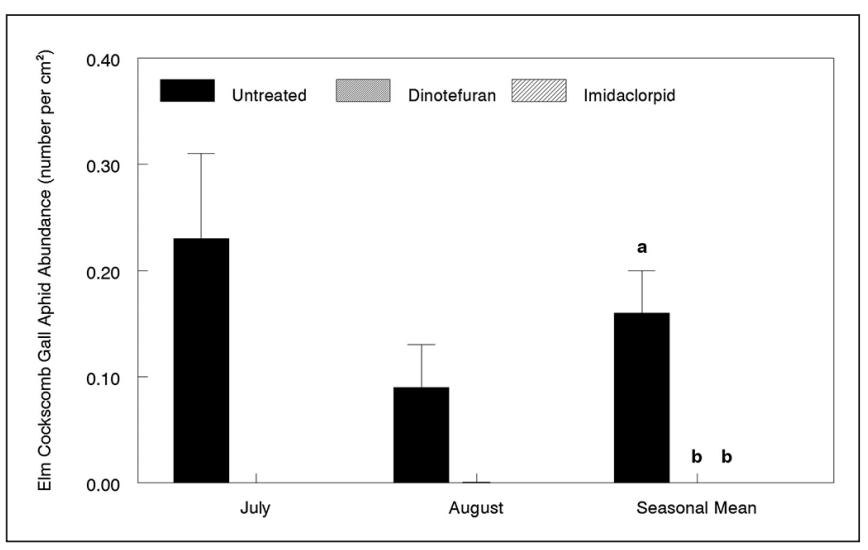

Figure 3. Effects of dinotefuran and imidacloprid on the abundance of Colopha ulmicola on two sample dates and seasonally (average of two dates). Bars represent means and vertical lines represent standard errors. Means that share a common letter do not differ significantly by an all-pairwise comparisons test $(P<0.05)$.

on ones treated with dinotefuran. These results are consistent with a previous study involving $T$. schoenei on elm (Szczepaniec et al. 2011), and with several other studies that reported elevated spider mite populations on woody plants following applications of imidacloprid (Sclar et al. 1998; Gupta and Krischik 2007; Szczepaniec 2009; Raupp et al. 2010; Szczepaniec and Raupp 2012a; Szczepaniec and Raupp 2012b). Several authors suggest that increased densities of spider mites following applications imidacloprid result from disruption of the activity of predators of spider mites or through enhanced reproduction of spider mites linked to improved plant quality, reduced plant defenses, or direct physiological stimulation of mite reproduction (Sclar et al. 1998; Gupta and Krischik 2007; Chiriboga 2009; Raupp et al. 2010; Szczepaniec et al. 2011; Szczepaniec and Raupp 2012a; Szczepaniec and Raupp 2012b; Szczepaniec et al. 2013). However, Szczepaniec and Raupp (2012a) make the strong case that changes in plant quality associated with applications of imidacloprid are sufficient to elevate populations of spider mites irrespective of the presence or absence of natural enemies.

The lack of response by $T$. schoenei to applications of dinotefuran are somewhat surprising as Szczepaniec et al. (2013) recently demonstrated that applications of other neonicotinoid insecticides including thiamethoxam and clothianidin elevated fecundity and populations densities of other spider mites in the genus Tetranychus associated with cotton and corn. Apparently, enhancement of spider mite performance and abundance will depend on the specific interactions among species of mites, host plants, and the type of neonicotinoid applied. It is noteworthy that imidacloprid and dinotefuran differ in their physical chemistry (Toscano and Byrne 2005; Wakita et al. 2005). The much greater water solubility of dinotefuran and its lower binding to organic matter, compared with imidacloprid, for example, may increase the rate of dissipation and leaching of dinotefuran from treatment sites. This may have an impact on the non-target effects of dinotefuran and explain some of the differences between these two neonicotinoids that were observed in the study. Because of the apparent differences in how these neonicotinoids affect spider mite populations, the study underscores the importance of testing the effect of each of the neonicotinoid insecticides on abundance of spider mites. 
Rust mites in the family Diptilomiopidae did not experience elevated populations in response to applications of either neonicotinoid. This result contrasts somewhat with previous studies that reported idiosyncratically elevated populations of rust mites and associated damage on elms and hemlocks treated with imidacloprid (Raupp et al. 2004; Szczepaniec et al. 2011).

Imidacloprid and dinotefuran significantly reduced the abundance of European elm scale on elm. This finding is completely consistent with previous accounts of neonicotinoids providing excellent control of E. spuria on elm (Sclar and Cranshaw 1996; Szczepaniec et al. 2011). Both insecticides also decreased numbers of the gall-forming aphid (C. ulmicola), illustrating that dinotefuran and imidacloprid are appropriate control measures in management of this pest on elms.

In summary, researchers found no evidence that applications of dinotefuran elevated populations of T. schoenei or Diptilomiopidae rust mites on American elm. Applications of imidacloprid did elevate populations of spider mites on elms. This is also relevant for management of pests attacking ash trees, especially as arborists in several states prepare to mitigate infestations of invasive borers such as emerald ash borer, Agrilus planipennis. Products containing imidacloprid and dinotefuran will be two of several management options (Herms et al. 2009; Szczepaniec et al. 2011), and data from the current study indicates that applications of dinotefuran are less likely than those of imidacloprid to result in a secondary outbreak of spider mites. Spider mites are secondary pests of most trees and rarely cause significant damage unless severe outbreaks of these pests cause yellowing and dropping of leaves. Even though such damage does not kill the trees, the significant loss of aesthetic value of elms following outbreaks of spider mites has been of serious concern to arborists. This study, along with previously published reports (Sclar et al. 1998; Szczepaniec et al. 2011), suggests that imidacloprid applications may trigger similar outbreaks of these pests and result in comparable damage to ash trees. These data, along with other factors, such as differences in cost of these insecticides, habitat, and soil type, should be taken into consideration when making pest management decisions.

Acknowledgments. The authors are grateful to the University of Maryland's Paint Branch Turf Research Facility for providing the field site for this study. We thank S. Grimard, K. H. and M. Vogel, and Z. Vogel for assistance in the field and laboratory. We are also grateful to two anonymous reviewers, whose comments greatly improved this manuscript. Grants from the National Research Initiative Competitive Grants Program of USDA 2005-00915, International Society of Arboriculture Tree Fund, and Gahan and Bamford Fellowships supported this research.

\section{LITERATURE CITED}

Ahern, R.G., S.D. Frank, and M.J. Raupp. 2005. Comparison of exclusion and imidacloprid for reduction of oviposition damage to young trees by periodical cicadas (Homoptera: Cicadidae). Journal of Economic Entomology 98:2133-2136.

Ali, A.D., D. Caldwell, J. Chamberlin, and J. Michael. 2010. Royal palm bug control with selected soil applied systemics. Arthropod management tests. 35:H1. doi: 10.4182/mat2010.H1.

Chiriboga, A. 2009. Physiological responses of woody plants to imidacloprid formulations. MSc thesis. The Ohio State University.

Cowles, R.S., M.E. Montgomery, and C.A.S. J. Cheah. 2006. Activity and residues of imidacloprid applied to soil and tree trunks to control hemlock woolly adelgid (Hemiptera: Adelgidae) in forests. Journal of Economic Entomology 99(4):12581-1267.
d'Eustachio, G., and M.J. Raupp. 2001. Application of systemic insecticides in relation to boxwood leafminer's life history. Journal of Arboriculture 27:255-262

Doccola. J.J., P.M. Wild, I. Ramaswamy, P. Castillo, and C. Taylor. 2003. Efficacy of Arborjet viper microinjections in the management of hemlock wooly adelgid. Journal of Arboriculture 29:327-330.

Frank, S. D., R. Ahern, and M.J. Raupp. 2007. Does imidacloprid reduce defoliation by Japanese beetles on linden for more than one growing season? Arboriculture \& Urban Forestry 33:392-396.

Frank, S.D., and A. Lebude. 2011. Season-long insecticide efficacy for hemlock woolly adelgid, Adelges tsugae (Hemiptera: Adelgidae), management in nurseries. Florida Entomologist 94(2):290-295.

Frank, S.D. 2012. Reduced risk insecticides to control scale insects and protect natural enemies in the production and maintenance of urban landscape plants. Environmental Entomology 41:377-386.

Gill, S., D.K. Jefferson, R.M. Reeser, and M.J. Raupp. 1999. Use of soil and trunk injection of systemic insecticides to control lace bug on hawthorn. Journal of Arboriculture 25:38-41.

Gill, S.A., J. Lutz, P.M. Shrewsbury, and S. Klick. 2002. Evaluation of the systemic insecticides imidacloprid and thiamethoxam applied as soil applications for control of boxwood leafminer on boxwood, 2000-2001. Arthropod Management Tests. <www.entsoc.org/Protected/AMT/AMT27/index.asp>

Gillman, J., and C. Rosen. 2000. Tree Fertilization: A Guide for Fertilizing New and Established Trees in the Landscape. University of Minnesota Extension Leaflet. WW-07410. <www.extension.umn. edu/distribution/horticulture/DG7410.html>

Gupta, G., and V.A. Krischik. 2007. Professional and consumer insecticides for management of adult Japanese beetle on hybrid tea rose. Journal of Economic Entomology 100:830-837.

Herms, D.A. 2003. The enemy within: Understanding the biology and management of borers. Tree Care Industry 14:8-17.

Herms, D.A., D.G. McCullough, D.R. Smitley, C. Sadof, R.C. Williamson, and P.L. Nixon. 2009. Northeast IPM Center. U.S. Department of Agriculture's Animal and Plant Health Inspection Service (USDA-APHIS) and the U.S. Forest Service, Northeastern Area, Forest Health Protection. 12 pp. <www.emeraldashborer.info/files/multistate_eab_insecticide_fact_sheet.pdf>

Lawson, A.B., and D.L. Dahlsten. 2003. Evaluation of systemic insecticides as a treatment option in Integrated Pest Management of the Elm Leaf Beetle, Xanthogaleruca luteola (Muller) (Coleoptera: Chrysomelidae). Journal of Economic Entomology 96: 1455-1462.

Layton, M. B., and S. Ma. 2009. Control of crapemyrtle aphids with media-applied systemic insecticides. Arthropod management tests. 2009. 34:G31. doi: 10.4182/amt.2009.G31.

Ludwig, S.W. 2011. Efficacy of insecticides against California red scale, 2010. Arthropod Management Tests 2011. 36:G1. doi: 10.4182/ amt.2011.G1.

Mullins, J.W. 1993. Imidacloprid - a new nitroguanidine insecticide, Vol. 524: Pest Control with Enhanced Environmental Safety. S.O. Duke, J.J. Menn, and J.R. Plimmer (Eds.). pp. 183-198.

Oliver J.B., D.C. Fare, N. Youssef, M.A. Halcomb, M.E. Reding, and C.M. Ranger. 2009. Evaluation of systemic insecticides for potato leafhopper control in field-grown red maple. Journal of Environmental Horticulture 27(1):17-23.

Oliver, J.B., D.C. Fare, N. Youssef, S.S. Scholl, M.E. Reding, C.M. Ranger, J.J. Moyseenko, and M.A. Halcomb. 2010. Evaluation of a single application of neonicotinoid and multi-application contact insecticides for flatheaded borer management in field grown red maple cultivars. Journal of Environmental Horticulture 28(3):135-149. 
Raupp, M.J., Shrewsbury, P.M. and D.H. Herms. 2012. Disasters by design: Outbreaks along urban gradients. In: Insect outbreaks revisited. P. Barbosa, D. Letourneau, and A. Agrawal (Eds.). Wiley-Blackwell, Oxford, UK. 27 pp.

Raupp, M. J., R. Webb, A. Szczepaniec, D. Booth, and R. Ahern. 2004. Incidence, abundance and severity of mites on hemlocks following applications of imidacloprid. Journal of Arboriculture 30:108-113.

Raupp, M.J., P.M. Shrewsbury, and D.A. Herms. 2010. Ecology of arthropod outbreaks in urban landscapes. Annual Review of Entomology 55:19-38.

Rebek, E.J., D.A. Herms, and D.R. Smitley. 2008. Interspecific variation in resistance to emerald ash borer (Coleoptera: Buprestidae) among North American and Asian ash (Fraxinus spp.). Environmental Entomology 37:242-246.

Sclar, D.C., D. Gerace, and W.S. Cranshaw. 1998. Observations in population increases and injury by spider mites (Acari: Tetranychidae) on ornamental plants treated with imidacloprid. Journal of Economic Entomology 91:250-255.

Sclar, D.C., and W.S. Cranshaw. 1996. Evaluation of new systemic insecticides for elm insect pest control. Journal of Environmental Horticulture 14:22-26.

Smitley, D.R., E.J. Rebek, R.N. Royalty, T.W. Davis, and K.F. Newhouse. 2010. Protection of Individual Ash Trees from Emerald Ash Borer (Coleoptera: Buprestidae) with Basal Soil Applications of Imidacloprid Journal of Economic Entomology 103(1):119-126.

Stewart, V.B., and T.A. Horner. 1994. Control of hemlock wooly adelgid using soil injections of systemic insecticides. Journal of Arboriculture 20:287-289.

Szczepaniec, A., and M.J. Raupp. 2007. Residual toxicity of imidacloprid to hawthorn lace bug, Corythuca cydoniae, feeding on cotoneasters in landscapes and containers. Journal of Environmental Horticulture 25:43-47.

Szczepaniec, A., S.F. Creary, K.L. Laskowski, J.P. Nyrop, and M.J. Raupp. 2011. Neonicotinoid insecticide imidacloprid causes outbreaks of spider mites on elm trees in urban landscapes. PLoS ONE 6(5): e20018. doi: 10.1371/journal.pone.0020018PloS. ONE.

Szczepaniec, A., and M.J. Raupp. 2012a. Effects of imidacloprid on boxwood spider mite (Acari: Tetranychidae) abundance and associated injury to boxwoods. Arboriculture \& Urban Forestry 38(2):37-39.

Szczepaniec, A., and M.J. Raupp. 2012b. Direct and indirect effects of imidacloprid on fecundity and abundance of Eurytetranychus buxi (Acari: Tetranychidae) on boxwoods. Experimental and Applied Acarology doi: 10.1007/s10493-012-9614-1.

Szczepaniec, A., M.J. Raupp, R.D. Parker, D. Kerns, and M.D. Eubanks. 2013. Neonicotinoid insecticides alter induced defenses and increase susceptibility to spider mites in distantly related crop plants. PLoS ONE 8:e62620.

Toscano, N.C., and F.J. Byrne. 2005. Laboratory and field evaluations of neonicotinoid insecticides against the glassywinged sharpshooter. Proceedings, Pierce's Disease Research Symposium. pp. 380-383. San Diego, California, U.S. Dec. 5-7, 2005.

Wakita, T., N. Yasui, E. Yamada, and D. Kishi. 2005. Development of a novel insecticide, dinotefuran. Journal of Pesticide Science: 30:122-123

Wang, B., R. Gao, V.C. Mastro, and R.C. Reardon. 2005. Toxicity of four systemic neonicotinoids to adults of Anoplophora glabripennis (Coleoptera: Cerambycidae). Journal of Economic Entomology 98:2292-2300.

Webb, R.A., J.R. Frank, and M.J. Raupp. 2003. Recovery of eastern hemlock from attack by hemlock woolly adelgid following treatment with imidacloprid. Journal of Arboriculture 29:298-302.
Young, L.C. 2002. The efficacy of micro-injected imidacloprid and oxydemeton-methyl on red gum eucalyptus trees (Eucalyptus camaldulensis) infested with red gum lerp psyllid (Glycaspis brimblecombei). Journal of Arboriculture 28: 144-147.

Zar, J. 1999. Biostatistical Analysis. Prentice Hall, Upper Saddle River, New Jersey, U.S.

Adrianna Szczepaniec (corresponding author)

Department of Plant Science

Plant Science - Box 2207A

Brookings, SD 57007

Brian B. Raupp

Department of Entomology

University of Maryland

College Park, Maryland 20742, U.S.

Michael J. Raupp

Department of Entomology

University of Maryland

College Park, Maryland 20742, U.S.

Zusammenfassung. Neonikotinoide Insektizide sind eine relative neue Klasse von Komponenten mit einer exzellenten Wirkung bei einer breiten Versammlung von bedeutenden Insektenschädlingen an holzigen Pflanzen. Unglücklicherweise wurde die Anwendung von einem Neonikotinoid, Imidacloprid, in Verbindung gebracht mit dem sekundären Ausbruch von verschiedenen Arten von Spinnmilben bei verschiedenen Bäumen und Büschen. Dinotefuran ist ein anderes neonikotinoides Insektizid, welches nun weltweit von Arboristen zur Bekämpfung von Insekten, einschließlich so lästigen Käfern wie dem Eschenbohrer verwendet wird. Forscher testeten eine Hypothese, dass Applikationen von Dinotefuran auf Amerikanische Ulmen (Ulmus americana) die Populationen von einer Spinnmilbe (Tetranychus schoenei) und Rostmilben der Gattung Diptilomiopidae erhöhen und fanden keine Hinweise, dass Dinotefuran die Dichte dieser Milben erhöht. Die Applikation von Imidacloprid erhöht die Dichte von T. schoenei, aber nicht Diptilomiopidae. Beide Neonikotinoide sind sehr effektiv bei der Bekämpfung von der Europäischen Ulmenschildlaus Eriococcus spuria, und einer gallenbildenen Ulmenlaus, Colopha ulmicola.

Resumen. Los insecticidas neonicotinoides son una clase relativamente nueva de compuestos con una excelente eficacia frente a un amplio conjunto de plagas de insectos clave de plantas leñosas. Desafortunadamente, el uso del neonicotinoide imidacloprid se ha relacionado con brotes secundarios de varias especies de ácaros de araña en diferentes árboles y arbustos. Dinotefuran es otro insecticida neonicotinoide ampliamente utilizado ahora por arboristas para gestionar los insectos, como el barrenador esmeralda del fresno. Las investigaciones probaron la hipótesis de que las aplicaciones de dinotefuran a olmos americanos (Ulmus americana) con poblaciones elevadas de ácaros de la araña roja, Tetranychus schoenei, y ácaros en la familia Diptilomiopidae, y no encontraron indicios de que dinotefuran elevara las densidades de cualquiera de los ácaros. Aplicaciones de imidacloprid elevaron las densidades de T. schoenei, pero no Diptilomiopidae. Los dos neonicotinoides son altamente eficaces en la reducción de la abundancia de la escama del olmo europeo, Eriococcus spuria, y el áfido agalla del olmo, Colopha ulmicola. 